\title{
Universal Jurisprudence and The CaSe for Legal Humanism
}

\section{IAN WARD*}

This article was given by the author as the 2000 Bowker Lecture at the University of Alberta, Faculty of Law. The author explores an interdisciplinary approach to legal theory by incorporating elements of law, political philosophy, and literature in a globalized, post-modern setting. He begins by stating that although there is presently a crisis in legal theory, such a crisis can be resolved through the creation of a distinct legal humanism which "can emerge from the dying embers of post-modernism." The author then examines the works of Wordsworth. Coleridge, Nietzsche, Lyotard, Derrida, Heidegger, Leibniz, Shelley, and Eliot, in order 10 reconceptualize the notions of humanity and human rights as understood in legal humanism. It is only through such a reconceptualization, he argues, that a universal jurisprudence faithful to the ideals of justice, charity, and sympathy can be finally brought to fruition.
L'auteur a remis cet article dans le cadre de la conférence Bowker 2000 de la faculté de droit de l'Université de l'Alberta. L'auteur y explore une démarche interdisciplinaire de la théorie juridique en incorporant des éléments de droit, de philosophie politique et de littérature dans un cadre postmoderne mondialisé. Il déclare tout d'abord que bien que la thèorie juridique soit actuellement l'objet d'une crise, cetle crise peut ètre réglée au moyen de la création d'un humanisme juridique distinct qui " peut émerger des décombres du postmodernisme ". $L$ 'auteur examine ensuite les auvres de Wordsworth, Coleridge, Nietzsche, Lyotard, Derrida, Heidegger, Leibniz. Shelley et Eliot afin de recréer les notions d'humanité et de droits de la personne telles qu'elles sont vues par l'humanisme juridique. Il estime que c'est uniquement au moyen d'une telle nouvelle conceptualisation qu'une jurisprudence universelle et fidèle aux principes de justice, de charité et de sympathie pourra enfin devenir réalité.

\section{TABLE OF CONTENTS}

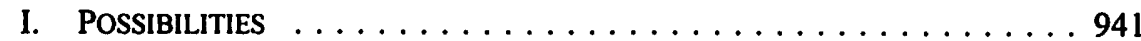

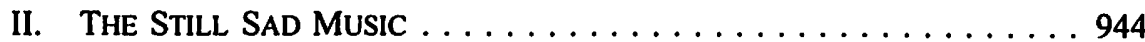

III. THE ABYSS $\ldots \ldots \ldots \ldots \ldots \ldots \ldots \ldots \ldots \ldots \ldots \ldots . \ldots \ldots 9$

IV. A UNIVERSAL JURISPRUDENCE $\ldots \ldots \ldots \ldots \ldots \ldots \ldots \ldots \ldots 953$

\section{Possibilities}

There is a distinct fin-de-siecle feel about legal theory; wallowing in the wake of realists and critical scholars, amidst the ruins of legal positivism, struggling through the intellectual mists of post-modernism. Modernism, we are often told is just worn out, no longer credible, to use the resonant phrase of the French philosopher, Jean-Francois Lyotard, "silenced" by the indescribable horrors of Auschwitz.' It is a mood heightened by the rapid transformation of international order during the second part of the twentieth century. Something, it is suggested, will have to change.

Professor of Law, Newcastle Law School, University of Newcastle, Newcastle upon Tyne, U.K. A version of this article was given as the Bowker lecture at the University of Alberta in September 2000. I am grateful to the Faculty of Law for their invitation to give the lecture. I should also like to thank Clare McGlynn for a number of helpful observations on earlier drafts of the article.

See generally J.-F. Lyotard, The Differend: Phrases in Dispute, trans. G. Van Den Abbeele (Minneapolis: University of Minnesota Press, 1988) [hereinafter Differend] at 3-8. 
The most compelling contemporary studies of this suggested crisis in legal theory are founded on the dynamics of this transformation. Neil MacCormick's Questioning Sovereignty perhaps best captures the sense of exhilaration, arguing that a legal theory that goes "beyond sovereignty" is a "profoundly exciting possibility that can become an actuality only if people truly grasp its possibility intellectually and in their political imagination." The "only if" is, of course, pivotal. As is the need to revitalize the "political imagination," an idea which has enjoyed a rather longer gestation in literary and political theory than it has in classical jurisprudence. The role of a revitalized "political imagination" is central to this article, for it will be suggested that an emergent jurisprudence of legal humanism will be founded on the interdisciplinary engagement of law, politics and literature.

But the step "beyond" sovereignty is only the start of the journey. MacCormick's thesis is more insidious. For it suggests that the entire edifice of legal positivism, of the "institutional theory of law," is no longer tenable. The "Benthamite Constitution" has "fallen." In its place, MacCormick recommends "legal philosophies" that can "open up practical possibilities without begging the question of where in politics lie the things of ultimate value, and what these are." ${ }^{3}$ MacCormick confesses to being a "diffusionist," but he is one whose value scepticism remains defined by the overarching pillars of a liberal constitutionalism that "shades over into social democracy." A jurist can decline to advocate values. But he cannot deny their presence in any constitutional tradition. The step "beyond" sovereignty remains a hesitant one. We shall return to MacCormick's constitutionalism in the final part of this article.

The dismissal of "institutional" theories of law is taken with even greater relish in William Twining's Globalisation and Legal Theory. In our "increasingly cosmopolitan" world, Twining opens, the time is "ripe for a revival of a more general jurisprudence." No community can any longer be said to be "self-contained." Globalization has cut across notions of both legal and political sovereignty. With the re-emergence of a "general" jurisprudence, one that "can transcend jurisdictions and cultures" and which "can address issues about law from a global and transnational perspective," must come the eclipse, at least partial, of "particular" jurisprudences. ${ }^{7}$ Whilst there may still be a place for "local particulars," jurisprudence must again become a universal conception. ${ }^{8}$

Whilst the "complexity" of globalization might lead to an ever more confused relation between "general" and "particular" jurisprudences, the underlying question which faces us now is as simple as it is stark, what are the "prospects for a genuine ius humanitatis dealing with the common heritage of mankind? And what will be its philosophical or

N. MacCormick, Questioning Sovereignty: Law, State and Nation in the European Commonwealth, (Oxford: Oxford University Press, 1999) [hereinafter Questioning Sovereignty] at vi.

lbid. at 78.

Ibid.

See also ibid. at 75-78, 172-74, 188-89.

W. Twining, Globalisation and Legal Theory (London: Butterworths, 2000) at 3.

Ibid. at 49.

See also ibid. at 3-4, 8, 47-49. 
political base?"' It is, indeed, the essential question. It is also one which, contra MacCormick, Twining argues lies at the heart of Bentham's legal thought. The "modern Benthamite," Twining avers, is a true "citizen of the world," one who respects the essential individuality, and thus humanity, of all. ${ }^{10}$

For Twining, complexity and humanity run together, and it is for this reason that the "particular" and the "general" can never be cleanly distinguished. There is an essential same-ness, but also an equally critical differentness, about humanity. Seeking recourse, like MacCormick, to the political "imagination," Twining alights upon the political and literary impressionism of Italo Calvino and de Sousa Santos." Legal orders are "mental maps," the construct of a multiplicity of impressions, of "complexes of social relations, ideas, ideologies, norms, concepts, institutions, people, techniques and traditions."'2 This is "diffusionism" on the grandest of scales. It is, in short, a post-modern critique, one which "emphasises the complexities and elusiveness of reality, the difficulties of grasping it, and the value of imagination and multiple perspectives in facing these difficulties." 13 But it is also one that is founded within a deeply modernist aspiration, to refound a "general" jurisprudence upon an essential notion of humanitas.

Essential notions of humanitas haunt Costas Douzinas's The End of Human Rights. According to Douzinas, human "rights" represent the "fulfilment" of the "promise" of modernity. Yet there is a very immediate paradox, as Lyotard notes. For the twentieth century has been saturated in the blood of mass murder. There is then a dissonance between the "promise" and the reality, a dissonance which has now insinuated itself into the centre of contemporary international legal theory. Against a discredited modernity, against the "boredom of analytical common-sense and its evacuation of political vision and moral purpose,"14 Douzinas wishes to align a "philosophical anti-humanism" which is, at once, a "defence of the human."15 It is, as we shall see in the second part of this article, a classic post-modern strategy, and one that is wracked with anxieties.

Tracing the genealogy of human "rights," from its expressions in classical jurisprudence through to its positive and utilitarian expressions, and on to the explosion of human "rights" rhetoric in late modernity, Douzinas seeks to locate some kind of demarcation between "humanity" and humanitas; an endeavour which, as we shall also see, is intrinsically Heideggerian. There is, at the root of this aspiration, a central paradox, as Douzinas readily admits; the necessary paradox which patrols a "universal" theory of difference. ${ }^{16}$ For Douzinas, as for Twining, the paradox is inescapable. Modernism, and its post-modern offspring, are irreducibly codependent.

Ibid. at 51.

See ibid. at 65-66, 91-105.

See ibid. at 137-40, 172, 212-13, 221-24, 243-44.

Ibid. at 172.

Ibid. at 243.

C. Douzinas, The End of Human Rights: Critical Legal Thought at the Turn of the Century (Oxford: Hart, 2000) [hereinafter End of Human Rights] at 4.

See ibid. at 1-4, 17-19, 121-31.

See ibid. at 136, 143-44. 
Three very different impressions of the contemporary state of legal theory, each displaying a degree of value scepticism, each flirting with theories of complexity, diffusionism, and pluralism. But each lingering too, gesturing toward some kind of constructive engagement with received theories of law, as well as with the demands of a changing world. Whilst deploying the rhetorical strategies of post-modernism, the "end" of sovereignty, the "end" of the discrete nation-state, the "end" of human rights, each glances back nostaligically to certain core principles of modernism, to a "general" jurisprudence, to a revitalised "human" rights, to a newly drawn European constitutionalism.

The purpose of this article is to suggest that there is indeed a nostalgia at the heart of the present crisis in legal theory. For, at the heart of the critical engagement between modernism and post-modernism, can be found what Lyotard, following Kant, terms the "abyss," the indeterminacy that both separates and attaches self and other. The engagement meets, in short, at humanity. It is for the privilege of describing "humanity" that modernism and post-modernism engage.

This article is, then, about humanity, about the possibility that a distinct legal humanism can emerge from the dying embers of the post-modern. It is a prescriptive thesis. The idea of humanity has been too long forgotten in the discourse of jurisprudence. And it is a descriptive thesis too. The time has come. It is the logic of the post-modern critique, its last will and testament. Before we take a closer look at post-modernism, and at the "general" jurisprudence which might, in a suitably ironic and paradoxical sense, describe its immanent logic, we must first reflect a little on the "still, sad music of humanity." Reinvesting a legal humanism depends upon us all listening a little more.

\section{The STILL SAD MUSIC}

But what should we listen for? And to whom should we listen? In the "stories of people's real diversity and complexity," according to Martha Nussbaum. In the "narrative imagination," the capacity "to think what it might be like to be in the shoes of a person different from oneself, to be an intelligent reader of that person's story, and to understand the emotions and wishes and desires that someone so placed might have."17 In a reawakened "sensitivity to the pain and humiliation of others,"18 according to Richard Rorty, in a "human rights culture" which will "owe nothing to increased moral knowledge, and everything to hearing sad and sentimental stories," 19 one which endeavours to nurture "moral progress" through the media "of sentiment rather than on the commands of reason." 20

N. Nussbaum, Cultivating Humanity: A Classical Defense of Reform in Liberal Education (Cambridge: Mass.: Harvard University Press, 1997) at 6, 10-11.

R. Rorty, Contingency, irony and solidarity (Cambridge: Cambridge University Press, 1989) at 198. R. Rorty, "Human Rights, Rationality, and Sentimentality" in S. Shute \& S. Hurley, eds., On Human Rights: The Oxford Amnesty Lectures 1993 (New York: BasicBooks, 1993) [hereinafter On Human Rights] 111 at 118-19.

Ibid. at 130. See also ibid. at 134. 
Someone who articulated a very real, and very passionate, "sensitivity to the pain" of others, and who strove mightily to engage the "narrative imagination" in the cause of humanity, was William Wordsworth. It is in poems such as "Incidents on Salisbury Plain," with its haunting image of the gibbet, the "spectacle of shuddering pain," that Wordsworth related his "sad and sentimental stories." When he wrote "Salisbury Plain," Wordsworth was just twenty-one, his famous ideological apostasy, and conversion to conservative humanism, yet to come. But he was already fully aware that a society which could triumph judicial murder was one which was devoid of a proper sense of "humanity."

In the summer of 1797 , it was reported to the Home Secretary, the Duke of Portland, that a "Sett of Violent Democrats" had taken up residence at Alfoxden in Somerset. They included a "Mr.Wordsworth," a "phylosopher," and the notorious radical Samuel Taylor Coleridge. They talked much of spies, particularly of a "Spy Nozy," and of revolution." There was indeed talk of revolution at Alfoxden. But it was not of the type anticipated by Portland's informant. It was altogether more subtle, and ultimately more destabilizing. For Wordsworth was contemplating post-modernism, the abandonment of ideology, of "institutional" theories of government.

As the weeks passed into months, whilst trying to make sense of Coleridge's increasingly frenetic outpourings on the subject of Kant, Schiller, and German metaphysics, Wordsworth was thinking ever more seriously about humanity, and about its incompatibility with the very idea of political ideology. The route to true freedom, he mused, might be more readily secured through language and the imagination, than through politics and ideology. By 1797, Coleridge was already in awe. He was, he admitted, "only a kind of Metaphysician," the type of man who is too readily seduced by ideology. But Wordsworth was something else, a "genius," someone who could glimpse an alternative politics that was not really politics at all. ${ }^{22}$

In the Preface to the Lyrical Ballads, which eventually emerged from these heady nights at Alfoxden, Wordsworth confirmed that henceforth his poetry must "speak a plainer and more emphatic language," the "language really used by men." 23 Yet, the "experiment" with language could not but carry a political import. The Lyrical Ballads were revolutionary not just because of their subject, the human condition, but because of how it was said, and who said it. Wordsworth returned the voice of humanity to humanity itself. A whole new audience was invited to become an active participant in political dialogue. And it was invited not simply to engage in political ideology, but in the politics of everyday life. The whole pretence of a distinction between the public and private lives

Spy Nozy was, of course, Spinoza. For a commentary on Portland's attempt to ascertain what was going on at Alfoxden, see N. Roe, Wordsworth and Coleridge: The Radical Years (Oxford: Oxford University Press, 1988) at 234-62; and K. Johnston, The Hidden Wordsworth: Poet, Lover, Rebel, Spy (New York: Norton, 1988) at 427-76, 490-91, 516-64.

For a description of Coleridge's relation to Wordsworth, see W. Hazlit, "My First Acquaintance with Poets," in Selected Writings, ed. by R. Blythe (Middlesex: Penguin Books, 1987) 43 at 58-63. For a general commentary, see R. Holmes, Coleridge: Early Visions (Middlesex: Penguin Books, 1989) at $152-59,185,191-98$. 
of human beings was cut away. It was this ideological iconoclasm which represented a real revolution.

It was in the following summer, of 1798 , that Wordsworth produced his great critique of humanism, his "Lines Composed a Few Miles Above Tintern Abbey."24 The apostasy was complete. The poet returned to nature and to humanity, to the invocation of a "warmer love." "The day [had] come when I again repose/ Here, under this dark sycamore." ${ }^{.25}$ And it is here:

In hours of weariness, sensations sweet, Felt in the blood, and felt along the heart;

And passing even into my purer mind,

With tranquil restoration: - feelings too

Of unremembered pleasure: such, perhaps,

As have no slight or trivial influence

On that best portion of a good man's life,

His little nameless, unremembered, acts

Of kindness and of love. ${ }^{26}$

Humanity is not saved by ideological manifestos, but by the "acts/ Of kindness and of love."27

It is, of course, an explicitly Pauline injunction, and one that bears immediate comparison, as we shall see, with the "universal jurisprudence" of Gottfried Wilhelm Leibniz. The language of "Tintern Abbey" resonates with this religious conviction. The "breath of this corporeal frame" is "become a living soul," when

While with an eye made quiet by the power

Of harmony, and the deep power of joy,

We see into the life of things. ${ }^{28}$

It is an inner vision of humanitas, as opposed to the outer vision of ideology. And it is indelibly confessional:

For I have learned

To look on nature, not as in the hour

Of thoughtless youth; but hearing oftentimes

The still, sad music of humanity,

Nor harsh nor grating, though of ample power

To chasten and subdue. ${ }^{29}$

W. Wordsworth, "Lines Composed a Few Miles Above Tintern Alley" in Poems, ed. by J.O. Hayden, vol. 1 (Middlesex: Penguin Books, 1977).

Ibid. at lines 9-10.

Ibid. at lines 27-35.

lbid. at lines 34-35.

Ibid. at lines $43-49$.

lbid. at lines 88-93. 
It is "Nature" which can redeem humanity, that can reassure it

that neither evil tongues,

Rash judgments, nor the sneers of selfish men,

Nor greetings where no kindness is, nor all

The dreary intercourse of daily life,

Shall e'er prevail against us..... ${ }^{\text {wo }}$

And it is here, finally, in the "warmer love"31 of the metaphysical other, that Wordsworth can reinvest once again "all my moral being." 32

The confessional humanism of "Tintern Abbey" can only be properly understood in the context of Wordsworth's particular apostasy. As he was putting the final touches to "Tintern Abbey," Wordsworth was already contemplating another confessional on a far greater scale, his vast epic on the subject of the French revolution, its idealism and its delusions, The Prelude. His initial enthusiasm for the events of 1789 could not be denied. "Bliss was is in that dawn to be alive/ But to be young was very Heaven," he famously exclaimed. ${ }^{33}$ And so, for the rest of his life, Wordsworth sought absolution, drafting revision after revision of the poem, ever more determined to confirm his abjuration.

The pivotal relation in The Prelude is between Wordsworth and Michel-Arnaud de Beaupuy, revolutionary soldier, idealist, and in the poet's eyes, humanist; a "meeker man/ Than this lived never."34 "Oft in solitude," Wordsworth recalled, "With him did I discourse, about the end/ Of civil government, and its wisest forms,"3s of "self respect, and virtue in the few." ${ }^{36}$ It was with Beaupuy that Wordsworth encountered

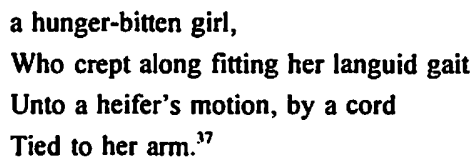

The impact of the girl was momentous. In "agitation," Beaupuy exclaimed, "Tis against that/ That we are fighting," and Wordsworth "with him believed/ That a benignant spirit was abroad/ Which might not be withstood." spirit, which justified the revolution, and it was with this spirit that Wordsworth sought to justify his own aberrant affinity with ideology.

\section{Ibid. at lines 128-32.}

Ibid. at line 154.

Ibid. at line 111.

W. Wordsworth, The Prelude, ed. by C. Baker (New York: Rinehart \& Co., 1948) at bk. 11, lines 108-109. 
But the "Dances of Liberty" were an illusion:

I looked for something that which I could not find, Affecting more emotion than I felt. ${ }^{39}$

Like so many of his compatriots, Wordsworth was horrified by the spiral into anarchy in 1792-3. Tempted by the "Babel-like" chatter of revolutionary ideologues, he had become a "bigot to a new idolatry," ${ }^{\circ 0}$ and turned away with a venom. He "shook the habit off/ Entirely and for ever."4l Henceforth it would be "In Nature's presence," in the "genuine liberty"42 and "absolute power" of the "Imagination" ${ }^{43}$ that he would seek his "repose." It would be within, in his own capacity to be "A sensitive being, a creative soul" a capacity which he shared with every other human being, every Beaupuy, every "hungerbitten girl" ${ }^{\prime 45}$ - that he would reinvest his own essential sense of humanity and justice.

Browning later referred to Wordsworth as a "lost leader." Hazlitt was venomous, not just because Wordsworth had turned against the ideals of 1789 , but because he had turned literature away from ideology. In his memorial essay "The Lake School," he later lent a grudging praise to the "new school" that Wordsworth had founded "on a principle of sheer humanity, on pure nature void of art," on the "levelling calculation of human nature."46 And in a complementary essay, "Mr. Wordsworth," Hazlitt voiced a deeper suspicion. The philosophy which Wordsworth espoused, "nothing loftier than human hopes; nothing deeper than the human heart," ${ }^{, 47}$ was itself an ideological strategy. Moreover, it was not just an ideology. Wordsworth, Hazlitt implied, was intent upon projecting humanism as a kind of theology. He strove to be "God of his own idolatry."48 It was this strategic acuity that Hazlitt grudgingly admired. In crushing ideology, Hazlitt insinuated, Wordsworth's "lofty philosophic tone," his "thoughtful humanity,"49 had itself become the essential ideology of romanticism, the "spirit of the age" indeed.

\section{THE ABYSS}

"God of his own idolatry." The image has thrilled, fascinated and horrified modernity. It certainly thrilled and horrified Friedrich Nietzsche. The assault against the "herd mentality" of Christianity was central to Nietzsche's thinking. Wordsworth would certainly not have approved Nietzsche and there is no evidence that Nietzsche approved Wordsworth. But he certainly approved Byron and Schiller, Hoelderlin and Wagner, and

Ibid. at bk. 9, lines 72-73.

Ibid. at bk. 12, lines 77 .

Ibid. at bk. 12, lines 204-205.

Ibid. at bk. 14, line 132 .

Ibid. at bk. 12, line 206.

Ibid. at bk. 12, line 207.

Ibid. at bk. 9, line 510 .

Hazlitt, supra note 22 at 217.

lbid. at 219.

Ibid. at 231.

Ibid. at 223.

See also ibid. at 219-21. 
the "aesthetic interpretation and justification of the world"sI which romanticism had tried to level against the tyranny of Socrates. In the 1871 Preface to The Birth of Tragedy, Nietzsche proclaimed "I am convinced that art is the supreme task and the truly metaphysical activity of this life." 52 Whilst the Socratic disciple prefers to spin the essential illusions of "sacred universal laws," it is the Dionysiac, the artist who embraces "pain and contradiction" and a "primal Oneness," who comes to understand an essential humanitas."

In a series of unpublished lecture notes, Nietzsche argued vigorously that the "task of art is to annihilate the State,"54 and the first step in this progress had to be the "overcoming" of positive "legality." 55 It was for this reason that Zarathustra, the matured Dionysus, the anti-Christ, was to be the great "destroyer" of laws, and the great destroyer of modernity. In a fervid passage in Thus Spoke Zarathustra, Nietzsche set Zarathustra as a new divinity, a divinity of the self. God is replaced by humanity. "Away with such a god!" Zarathustra screams, "Better no god, better to produce destiny on one's own account, better to be a fool, better to be God oneself." 56 Better to be God, as Hazlitt insinuated, of your "own idolatry." Hazlitt had prophesied the Nietzschean epilogue to Wordsworth's humanist critique.

Inheriting this critique, a generation of postmodernists and deconstructionists have sought to further destabilize the pretensions of modernism, and the jurisprudence which underpins it. ${ }^{57}$ According to Jean-Francois Lyotard, the "postmodern affliction" [lies in the] foreclosure of the Other," 58 a strategy that is consciously jurisprudential, effected by the deployment of "particular" jurisprudences in the annihilation of universal ideas of humanitas. In The Differend, Lyotard argues that the post-modern "project" must be concentrated on this jurisprudential struggle. Revisiting the idea of the sensus communis which Kant placed at the centre of his analysis of the beautiful in the Critique of Judgment, Lyotard suggests that a sensus communis can furnish an alternative jurisprudence in which the "community of addressors and addressees is called forth immediately, without the mediation of any concept, by feeling alone." 59 The sense of the primordial and the romantic is tangible. Such a "community" is a community of "taste." 60

F. Nietzsche, The Birth of Tragedy: Out of the Spirit of Music, trans. S. Whiteside, ed. by M. Tanner (London: Penguin Books, 1993) at 8.

Ibid. at 13.

See ibid. at 7, 29, 41, 85-87. For a discussion of Nietzsche's often fraught relationship with the "romantic" poets, see R. Hayman, Nietzsche: A Critical Life (London: Weidenfeld and Nicolson, 1995) at 37-49, 109-110.

Hayman, ibid. at 124.

See ibid. at 131, 135-36, 224-25, 262.

F. Nietzsche, Thus Spoke Zarathustra, trans. R.J. Hollingdale (Baltimore: Penguin Books, 1967) at 274.

For a general discussion of the impact of Nietzsche on post-modern legal and political thought, see D.W. Conway, Nietzsche \& the Political (London: Routledge, 1997), especially at 6-27 and 122-42. J.-F. Lyotard, "The Other's Rights," trans. C. Miller \& R. Smith in S. Shute \& S. Hurley, eds., On Human Rights, supra note 19, 135 at 146.

Differend, supra note 1 at 169.

Ibid. 
The role of the Kantian aesthetic is a challenging, and essential one. In his Lessons on the Analytic of the Sublime, Lyotard reaffirms the derivations of the post-modern critique from within the great Kantian "irruption," from the suggestion that the analytic of the sublime and the beautiful might be inextricable from Kant's ethical philosophy. The "reflective" faculty of judgment is, he suggests, the essential "bridge" over the Kantian "abyss," the central modernist fiction that aesthetics and ethics are discrete. ${ }^{61}$ It is with this faculty, Lyotard has argued elsewhere, that a postmodernist critique can reinvest a conception of humanitas in modern political thought. It will, he concludes, be a "posthumanist" humanism. ${ }^{62}$

It is striking that it was the attempt to pass over the Kantian "abyss" which came to dominate Coleridge's thinking during the later years of the 1790s and the first decade of the nineteenth century. Like Wordsworth, Coleridge emerged from the fervid atmosphere of Alfoxden convinced that ideology had forgotten sensibility. It was Kant, and especially the Critique of Judgment, which "took possession" of the poet "as with a giant's hand," who suggested that the ethics of the "moral self," the "Science of Being" as he called it, could not be distinguished from the aesthetics of "reflective judgment." Political imagination, the ability to nurture a politics of "sensibility," Coleridge concluded from his studies of Kant, is a "positive command of the moral law."

In chapter twenty-two of the Biographia Literaria, a paean to Wordsworth's humanist critique, Coleridge identifies his "characteristic excellence" in the "correspondent weight and sanity of the Thoughts and Sentiments." Echoing Wordsworth's own elision of spirituality and Platonic romanticism, and the overarching capacity of "reflective judgment," Coleridge pays homage to his

meditative pathos, a union of deep and subtle thought with sensibility; a sympathy with man as man; the sympathy indeed of a contemplator, rather than a fellow-sufferer or comate ... but of a contemplator, from whose view no difference of rank conceals the sameness of the nature; no injuries of wind or weather, of toil, or even of ignorance, wholly disguise the human face divine. ${ }^{\text {(t) }}$

Coleridge, like Hazlitt, detected the "God of his own idolatry" in the aspirations of political romanticism, and anticipated the paradox which was to lie at the heart of the post-modern critique.

J.-F. Lyotard, Lessons on the Analytic of the Sublime, trans. E. Rottenberg (Stanford: Stanford University Press, 1994) at 6-19.

See J.-F. Lyotard, "The General Line," in Political Writings, trans. B. Readings \& K. Paul (Minneapolis: University of Minnesota Press, 1993) at 108-11. For a discussion of the political implications of Lyotard's humanist critique, see B. Readings, Introducing Lyolard: Art and Politics (London: Routledge, 1991), especially at 137-39.

S.T. Coleridge, Biographia Literaria or Biographical Sketches of My Literay Life and Opinions, ed. by G. Watson (London: J.M. Dent \& Sons, 1984) [hereinafter Biographia Literaria] at 87-90, 14168, 175. For a discussion of Coleridge's engagement with Kant, see N. Leask, The Politics of Imagination in Coleridge's Critical Thought (London: MacMillan Press, 1998) at 77-123. Sec also R. Holmes, Coleridge: Darker Reflections, 1804-1834 (New York: Pantheon Books, 1998) at 360-61, 398-409. 
Another who has most readily appreciated the humanist affinities of a post-modern ethics is Jacques Derrida. The politics of deconstruction is founded on the need to reinvest a sense of humanity. In his essay "Before the Law," Derrida has argued that the ability to exercise judgment is the defining quality of humanity, whilst the capacity to do so is one that lies "beyond" the law. ${ }^{65}$ The extent to which deconstruction is founded on an attempt to reinvest a post-modern humanism is evidenced still further in "The Force of Law," in which Derrida suggests that the role of positive law, to mediate between "self" and "other," is one that has been consciously developed in order to suppress humanitas. ${ }^{66}$

It is this evocation of the "Other" which has seduced post-modern jurisprudence, tempting it with a "legality of the felt." ${ }^{, 67}$ Drucilla Cornell's The Philosophy of the Limit, for example, is founded on the Derridean attempt to reconfigure the "ethical relation" of the "Other" in distinctly aesthetic terms. ${ }^{68}$ Elsewhere she has argued that the "responsibility" of an ethics of deconstruction remains that of preserving the "disjuncture between law and justice" 69 in the cause of "fundamental humanity."70

Such Derridean attempts to reinvest an ethical deconstructionism are premised on Martin Heidegger's attempt to reach back beyond modernity in order to grasp a primordial sense of humanitas. ${ }^{11}$ There is an immediate and striking affinity between Heidegger's incessant invocation of nature against technology and Wordsworth's. Theirs is a shared crusade. When Heidegger condemns a hydroelectric plant on the Rhine in his essay "The Question Concerning Technology," he does so in a way that resonates with Wordsworth's castigation of the "rash assault" with which the builders of the Kendal and Windermere railway strive to destroy the "beautiful romance/ Of nature."72 For both, the "task of thinking," to use Heidegger's familiar phrase, is to retrieve a sense of humanity from the tyranny of utilitarian modernity.

In his "Letter on Humanism," which Heidegger levelled against Jean-Paul Sartre's attempt to recast existentialism as an intrinsically humanist and thereby modernist philosophy, Heidegger desperately tried to distinguish "humanism" from a primordial humanitas. "Humanism is opposed," he alleged, "because it does not set the humanitas

J. Derrida, "Before the Law" in D. Attridge, ed., Acts of Literature (New York: Routledge, 1992) 181 at $181-220$.

J. Derrida, "The Force of Law: The Mystical Foundation of Authority" (1990) 11 Cardozo L. Rev. 925.

C. Douzinas, P. Goodrich \& Y. Hachamovitch, eds., Politics, Postmodernity and Critical Legal Studies: The legality of the contingent (London: Routledge, 1994) at 22, 26.

D. Cornell, The Philosophy of the Limit (New York: Routledge, 1992) at 62.

D. Cornell, Beyond Accommodation: Ethical Feminism, Deconstruction, and the Law (New York: Routledge, 1991) at 116.

See also ibid. at 115-16.

"The clearest acknowledgement of this relation between Derrida and Heidegger can be found in J. Derrida, Of Spirit: Heidegger and the Question, trans. G. Bennington \& R. Bowlby (Chicago: University of Chicago Press, 1989). See also R. Beardsworth, Derrida \& the Political (London: Routledge, 1996) at 98-122.

7 See M. Heidegger, "The Question Concerning Technology" in Basic Writings: from Being and Time (1927) to The Task of Thinking (1964), ed. by D.F. Krell (New York: Harper and Row, 1977) [hereinafter Basic Writings] at 297-98. 
of man high enough." ${ }^{73}$ Modernism had sequestrated humanity. The reassertion of humanitas is "essential to the thinking of Being," which itself lies at the very centre of Heidegger's attempt to overcome the metaphysics of modernity:

To think the truth of Being at the same time means to think the humanity of homo humanus. What counts is humanitas in the service of the truth of Being, but without humanism in the metaphysical sense. ${ }^{74}$

In his End of Human Rights, Douzinas cites Heidegger as a paradigm of the postmodern critique of positive "rights," a conception of right which "necessarily violates the demand of justice."75 To establish a right is to establish a contest between self and other. There must be a priority in which rights are placed at the service of humanity, rather than humanity in the service of right. The priority is well articulated in Emmanuel Levinas' idea of "alterity." According to Levinas, "[m]y freedom and my rights, before manifesting themselves in my opposition to the freedom and rights of the other person, will manifest themselves in the form of responsibility, in human fraternity."

Douzinas is seduced by the ethics of "alterity." "Being is being together, being with others," he admits, an irreducible admission of essential humanity. ${ }^{77}$ And he is tempted by a post-modern "utopia" which can protect the "integrity of unique beings in their existential otherness, by promoting the dynamic realisation of the freedom with others."78 This, he emphasizes, is an "imaginary," one which is nurtured by "memories of fear, tales of pain and suffering and the experience of oppression." Alterity demands that we listen.

The idea that "fraternity" might underpin a post-modern political ethics has found a recent echo in Derrida's Politics of Friendship. The "very work of the political," Derrida suggests, "amounts to creating (to producing, to making, etc.) the most friendship possible." It is the primal characteristic of politics, and of humanity. It is "friendship" which gears relations between individuals, providing the necessary, if necessarily contingent, shared understandings of "truth, freedom, necessity, and equality." ${ }^{11}$ It is, moreover, this "friendship" which underpins any credible conception of "democracy." There can be no free and equal relationship between individuals without a prior appreciation of their humanity, "no deconstruction without democracy, no democracy without deconstruction." Above all, it is friendship which provides hope, which aspires to a better future, and which, in so doing, stresses the ultimate irrelevance of positive law. ${ }^{83}$

M. Heidegger, "Letter on Humanism" in Basic Writings, ibid. at 210.

Ibid. at 231.

C. Douzinas, supra note 14 at $345-46,368$.

Ibid. at 355.

lbid. at 320 .

Ibid. at 341.

Ibid. See also $319,380$.

J. Derida, Politics of Friendship, trans. G. Collins (London: Verso, 1997) at 8.

Ibid. at 100.

See ibid. at 101-105.

See also ibid. at 194, 198-99, 306. 
The humanitas for which Wordsworth and Heidegger both strove, and which lures Derrida and Douzinas, the humanitas which had been objectivized in Aristotle's "rational animal," cannot be detached from its modern sequestration. Wordsworth was happy to reconcile a conception of humanity within romanticism. Heidegger struggled against it. Just as he thought that Nietzsche had been trapped by modernity, and Sartre also, so Heidegger increasingly feared that he too would fall victim to the same intellectual sequestration. ${ }^{84}$ In Of Spirit: Heidegger and the Question, Derrida suggests that Heidegger's attempt to detach humanitas from humanity was a necessary, but ultimately inevitable, failure. For it, like indeed deconstruction itself, is an engagement with, and within, modernity. ${ }^{85}$

\section{A UNIVERSAL JURISPRUDENCE}

If legal theory is experiencing something of a crisis today, it is certainly not for the first time. Three centuries ago, Gottfried Wilhelm Leibniz was just as convinced that the jurisprudence which, for him, underpinned European civilization was threatened by the anarchic horrors of Hobbism. Whereas modern jurists have tended to react to the intellectual challenges of Nietzsche, Heidegger, and Derrida with a mixture of horror, apprehension, and bewilderment, classical jurists of the early eighteenth century viewed the likes of Hobbes, and acolytes such as Locke and Hume, with a comparable degree of distaste.

At the very heart of Leibniz' political philosophy was a nostalgic longing for a reunited Europe, a reinvested respublica Christiana secured once more on solid Aristotelian foundations. There were immediate political and personal reasons for this nostalgia. For much of his life, Leibniz served as a court adviser, effectively the propagandist-in-chief, of the house of Hanover. And what Hanover feared most of all was a strong and aggressive France. Leibniz was convinced that the ambitions of France could only be effectively held in check by a reunited respublica within which all the emergent nationstates of Europe would be rendered subservient, not just to a church, but to an overarching Christian public philosophy. It was for this immediately practical reason that jurisprudence mattered so very much to Leibniz. More than that, it was for this reason that Leibniz craved a truly "universal" jurisprudence. ${ }^{86}$

For Leibniz, the sorceror of "particular" jurisprudences was Thomas Hobbes, the philosopher who, as he alleged in The Common Concept of Justice, sought to replace God with a new "religion" of the "state." ${ }^{87}$ Leibniz vehemently opposed the idea that

$\mathbf{3 4}$

86

See his comments in M. Heidegger, "The End of Philosophy and the Task of Thinking" in Basic Writings, supra note 72 at $374-75$.

see J. Derrida, Of Spirit: Heidegger and the Question, trans. G. Bennington \& R. Bowlby (Chicago: University of Chicago Press, 1989) at 47-55.

For a discussion of the general historical and intellectual context within which Leibniz wrote, see C.J. Friedrich, "Philosophical Reflections of Leibniz on Law, Politics and the State" in H.G. Frankfurt, ed., Leibniz: A Collection of Critical Essays (Notre Dame: University of Notre Dame Press, 1976) 47 at $47-51$.

See G.W. Leibniz, Political Writings, $2 \mathrm{~d}$ ed., trans. P. Riley (Cambridge: Cambridge University Press, 1988) at $46-50,61$. 
sovereignty could be purely political. The legitimacy of any community must be described by certain principles of "universal jurisprudence." Otherwise there is nothing to protect humanity against the venal ambitions of any number of absolute tyrants. Or French kings, who, as he commented in his Mars Christianissimus, "recognize no longer any judge but the sword." If "we listen to Hobbes," he confirmed, "there will be nothing in our land but out-and-out anarchy."

Against Hobbes stood the revered figure of Aristotle, the master of "universal" jurisprudence, the man who placed legal theory within a wider public philosophy that was itself fashioned around a fundamentally humanist theory of ethics. A proper, "universal" concept of "justice," must be one that tends to the "good" of the whole community for, as Leibniz affirms "one always finds his own good in the general good." on the Principles of Pufendorf, Leibniz paid fulsome homage to Aristotelian natural justice:

Aristotelian philosophy, bases all of the virtues splendidly on universal justice; and we owe it not only to ourselves, but also to society, above all to that in which we find ourselves with God, by the natural law written in our hearts, that we have a soul imbued with free thoughts, and a will which tends constantly toward the just. ${ }^{90}$

Steeped in the catholicism from which a distinct European humanism emerged during the late fifteenth and sixteenth centuries, Leibniz refined the Aristotelian "rational animal," adding two essential components. The first of these was the Augustinian "City of God." The Platonic notion of totality, which underpinned St. Augustine's City of God, ${ }^{91}$ also lay at the heart of Leibniz' philosophical "architectonic,"his famous monadology; a kind of Christianised atomism. In his Monadology, Leibniz held that "[t]he totality of all spirits must compose the City of God, that is to say, the most perfect state that is possible."92 For "[t]his City of God, this truly universal monarchy, is a moral world in the natural world, and is the most exalted among the works of God." ${ }^{93}$ Following St. Augustine, Leibniz placed civil law within a wider public philosophy of the earthly City of God, which was itself nothing other than a "sufficient" emanation of the City of Heaven. ${ }^{94}$

See ibid. at 118-19, 136-45. For commentaries on Leibniz' engagement against Hobbes, see P. Riley, Leibniz' Universal Jurisprudence: Justice as the Charity of the Wise (Cambridge, Mass.: Harvard University Press, 1996) at 36-38, 52, 93-96, 205-15. See also N. Jolley, “Leibniz on Hobbes, Locke's Two Treatises and Sherlock's Case of Allegiance" (1975) 18 Hist. J. 21, who argues that Leibniz' particular opposition to Hobbes was triggered by the reproduction of a number of Hobbes' ideas in the controversy surrounding the so-called legitimacy of the "Glorious Revolution" of 1688. Leibniz, supra note 87 at 60 . See also ibid. at 50,57. For a commentary on Leibniz' Aristotelianism, see Riley, ibid. at 72-74, 206-207, 273-74. Leibniz, supra note 87 at 69.

91 Augustine, Saint, Bishop of Hippo, City of God, ed. and trans. by J.W.C. Ward (London: Oxford University Press, 1963).

$92 \quad$ lbid. at 3 .

33 lbid.

94 The Monadology was firmly cast in the mould of St. Augustine's City of God. For a discussion of their affinity, see Friedrich, supra note 86 at 50-56 and Riley, supra note 88 at 3-4, 51-88, 162-64, 193-95. 
The idea of a "universal" public philosophy was then rooted within a classical conception of divine justice. In words which echo those to be found in Questions 90-94 of St. Thomas Aquinas's Summa Theologiae, in his Opinion on the Principles of Pufendorf, Leibniz suggested that in the "science of law ... it is best to derive human justice, as from a spring, from the divine, to make it complete." jurisprudence," he continued, must be understood as an expression of "rules which are common" to divine and civil law. ${ }^{96}$ Rules which, moreover, pervade the practice of all aspects of life. A "universal jurisprudence," for Leibniz, was not just a theory of law, but of life. It defines humanity.

The second component which Leibniz placed at the heart of his humanism was the Pauline idea of justice as "charity," or more particularly the "charity of the wise," a "habit of loving" which defines the virtuous Christian and which, moreover, is most likely to be found in the educated godly magistrate. ${ }^{97}$ Charity is an innately jurisprudential concept, one which should determine all human inter-actions, a "universal benevolence, whose fulfillment the wise carry out conformably to the dictates of reason so as to obtain the greatest good." 98 In a short treatise on True Piety, Leibniz affirmed that "one cannot love God, who is invisible, if one does not love his neighbour, who is visible." Moreover, those, by which Leibniz clearly intended to implicate the Hobbists, who "reduce justice to rigor" and nothing more, "fail altogether to understand that one cannot be just without being benevolent."

The voluntaristic element is essential, maintaining a critical affinity with the original injunctions found in St. Paul's Epistles and in Aquinas, whilst also pointing to their further refinement in Kant's categorical imperative. ${ }^{100}$ Leibniz fully accepted the received Thomist wisdom, that God vested in humanity the ability to distinguish good from bad. It is the essential frame of moral responsibility, as it is for a "universal jurisprudence" indeed. The essential guide to moral responsibility, to a jurisprudence of charity, remained that which could be found in chapters twelve and thirteen of the Epistle to the Romans, "Owe to no man any thing, but to love one another: for he that loveth another hath fulfilled the law."101

Leibniz, supra note 87 at 69.

Ibid.

Unsurprisingly, such an attitude tended Leibniz toward a particular approval of aristocratic forms of government: see "Portrait of the Prince" in ibid. particularly at 98-99. For a discussion of Leibniz' aristocratic affinity and the extent to which it was tied to his idea of "justice as charity," see D.J. Den Uyl, "The Aristocratic Principle in the Political Philosophy of Leibniz' (1977) I5 J. Hist. Philos. (3d) 281.

Riley, supra note 88 at 60 . See also ibid. at $58-59$.

Ibid. at 19.

For examples of Leibniz' imperative, see Leibniz, supra note 87 at 56-57: “One could say, then, that justice, at least among men, is the constant will to act, so far as is possible, in a way such than no one can complain of us, if we would not complain of others in a similar case." For a commentary on the relation between Leibniz' imperative and Kant's, see Riley, supra note 88 at 79-81.

Rom. 13:8, King James Version. See also Rom. 13:10 and 1 Cor. 13:1-13. For a discussion of Leibniz' affinity with the Pauline tradition in Christian theology, see Riley, ibid. at 4-7, 18-19, 108$16,128-30,142-44,159-60,172-73$. 
In his most substantial commentary on "universal justice as charity," the Codex Iuris Gentium, Leibniz placed a particular stress on the impressionistic nature of such a jurisprudence and on the necessary and "sufficient" function of the imagination in perfecting a Christian humanism: "Charity is a universal benevolence, and benevolence the habit of loving or of willing the good. "Love then signifies rejoicing in the happiness of another, or, what is the same thing, converting the happiness of another into one's own." 102 In a passage which, once again, anticipates Kant's engagement with the "critique of judgment," Leibniz then goes onto employ a consciously aesthetic metaphor:

And since the contemplation of the beautiful is pleasant in itself, and a painting of Raphael affects a sensitive person who understands it, although it brings him no [material] gain, so that he keeps it in his [mind's] eye, as the image of a thing which is loved; when the beautiful thing is itself capable of happiness, this affection passes over into pure love. ${ }^{103}$

What art can do, like literature indeed, is encourage the "men of our times to humanize themselves." 104 And it is also what jurisprudence should do, to resist the Hobbesian attempt to translate legal science into a study of particular governments, and instead to embrace once again the Aristotelian notion that justice is a matter, at its root, of cultivating the "friendships" which define humanity. ${ }^{105}$

\section{FAMILIAR ACTS?}

There is, of course, a crucial question: is Leibniz' "universal jurisprudence" of relevance to contemporary debates about law and humanity? Obviously, it must be understood within its particular context, most immediately that of a Europe that hovered between a nostalgic longing for the principles of a late medieval respublica Christiana and a cautious enthusiasm for emergent ideas of political Enlightenment. But then all theories of law are constrained by historical context. Even the post-modern, as we have already noted, is tied inextricably to Nietzsche's confrontation with Aristotle; a confrontation that not only prefigures Heidegger's, and Derrida's with Heidegger, but which also resonates with Leibniz' invocation of Aristotle against Hobbes.

In an eloquent passage at the heart of Questioning Sovereignty, MacCormick suggests that a reconfigured Europe should embrace once again the classical humanist idea of a commonwealth of commonwealths, a polity that would "comprise a group of people to whom can reasonably be imputed some consciousness that they have a 'common weal,' something which really is a common good." 106 In such a Europe, "both member states and the Union are commonwealths,"

Leibniz, supra note 87 at 171.

Ibid. In his autobiographical Flight to Italy, Goethe recalls being driven to tears by the intense sense of humanity which he felt on seeing Raphael's Story of Psyche. It is a striking parallel and one that would have been fully appreciated by Wordsworth. See J.W. Goethe, The Flight to Italy: Diary and Selected Letters, trans. and ed. by T.J. Reed (Oxford: Oxford University Press, 1999) at 34-35. Leibniz, supra note 87 at 196. See generally ibid. at $195-96$. Supra note 2 at 143.

lbid. 
interest" and a "common good." Commonwealth, accordingly, "seems a natural term here to use." 108 So, too, as Larry Sidentop has asserted in his comparable study of European public philosophy, is the term respublica Christiana. ${ }^{109}$ And so, too, is the term "universal jurisprudence." The kind of "commonwealth" to which MacCormick gestures is the kind which jurists from Aquinas to Hooker to Leibniz have all rooted in an Aristotelian political theology.

In our modern, determinedly secular, age, perhaps the most unsettling aspect of Leibniz' "universal jurisprudence" and legal humanism is its reliance on Thomist political theology. If God is indeed dead, can we take Leibniz seriously? The answer can be given in the affirmative, as both MacCormick and Siedentop both imply. If we can take Wordsworth's humanism seriously, then we can take Leibniz' seriously too. Humanism is not the preserve of theology, any more than it is the preserve of modernism or postmodernism. It exists, as Wordsworth emphasised, quite outwith any ideological affinity. Indeed, it exists precisely so that we can imagine politics outwith ideology.

Two final commentaries, both taken from the generations which immediately followed Wordsworth, and which struggled mightily to reconcile the onslaught of positive ideology with a desire to somehow preserve the aesthetic sentiment of humanity.

In the Preface to his The Revolt of Islam, the experimental tone of which is so immediately resonant of the Preface to the Lyrical Ballads, Percy Bysshe Shelley announced "an experiment on the temper of the public mind," written with the hope of rekindling a "virtuous enthusiasm for those doctrines of liberty and justice, that faith and hope in something good, which neither violence nor misrepresentation nor prejudice can ever totally extinguish among mankind." 110 Writing in the spirit of Spencer and Milton, Shelley determined that the ultimate responsibility of the poet always lay in expressing the "love of mankind."'"

The Revolt of Islam is Shelley's immediate commentary on the French revolution, and thus also on the continuing debate regarding the accommodation of ideology with sentiment. Like Wordsworth, Shelley recognised the tension between literature and ideology, but unlike Wordsworth he saw it as a creative tension. It is "human words" which "found sympathy/ In human hearts." 12 The theme was developed further in Prometheus Unbound, a work which provides a striking foretaste of the kind of agonies which were to later immerse Nietzsche and Heidegger in their attempts to retrieve a primordial sense of humanitas. Here Shelley, too, craves an essential humanity, one untrammelled by the perversions of theology and ideology, one which can "bind the human heart." In the end, he projects a politics which is legitimated only by human "love," an idyll of

\footnotetext{
tan Ibid.

109 See L. Siedentop, Democracy in Europe (London: Penguin Group, 2000) at 189-214.

110 P.B. Shelley, Poetical Words, ed. by T. Hutchinson (London: Oxford University Press, 1968) at 32.

i11 Ibid. See generally ibid. at 32-35.

112 P.B. Shelley, The Revolt of Islam in Poetical Works, ed. by T. Hutchinson (London: Oxford University Press, 1968) at canto IX, verse IX, lines 3541-42.
} 
Man, one harmonious soul of many a soul,

Whose nature is its own divine control,

Where all things flow to all, as rivers to the sea;

Familiar acts are beautiful through love. ${ }^{113}$

In the generation following Shelley, in the midst of a nineteenth century struggling to come to terms with God's imminent "funeral," George Eliot fleshed out further the possibility of a poetic humanism, founded on Christian ethics, but not determined by its theology. ${ }^{114}$ As she turned against institutional theology, against God indeed, Eliot took with her the core of Christian humanism. As she observed in her essay "Evangelical Teaching," the "idea of God is really moral in its influence - it really cherishes all that is best and loveliest in man - only when God is contemplated as sympathizing with the pure elements of human feeling, as possessing infinitely all those attributes which we recognize to be moral in humanity."115 The "idea of God," she continues, "who not only sympathizes with all we feel and endure for our fellow-men, but who will pour new life into our too languid love, and give firmness to our vacillating purpose, is an extension and multiplication of the effects produced by human sympathy."116

And no one has appreciated better than Eliot the irreducible affinity between literature, politics and humanity. "The greatest benefit we owe to the artist, whether painter, poet, or novelist," she affirmed in her Natural History of German Life, "is the extension of our sympathies." 117 For "[a]rt is the nearest thing to life; it is a mode of amplifying experience and extending our contract with our fellow-men beyond the bounds of our personal lot." 118 Where "[a]ppeals founded on generalizations and statistics require a sympathy ready-made," the "moral sentiment" which a "great artist" can describe, surprises even the trivial and the selfish into that attention to what is apart from themselves." 19

This is the spirit of a "universal" jurisprudence, and of a reinvested legal humanism, one in which a theory of law is so much more than an analysis of cases and statutes,

P.B. Shelley, Prometheus Unbound in Poetical Works, ed. by T. Hutchinson (London: Oxford University Press, 1968) at act IV, lines 400-403.

The funereal metaphor is taken from Thomas Hardy's poem "God's Funeral" and provides the focus for A.N. Wilson's discussion of theological crisis in nineteenth century England. See A.N Wilson, God's Funeral (New York: W.W. Norton \& Company, 1999), especially the discussion on Eliot at 129-52.

In G. Eliot, Selected Essays, Poems, and Other Writings, ed. by A.S. Byatt \& N. Warren (London: Penguin Books, 1990) at 66.

Ibid. Eliot's humanism was hugely influenced by the German Higher Critics Strauss and Feuerbach, whose work she translated while working for the Westminster Review. The centrepiece of Higher Critical Scholarship was the assertion that Christianity was merely a metaphor for humanism. For a commentary on this influence on Eliot, see M.S. Vogeler, "The Choir Invisible: The Poetics of Humanist Piety" in G.S. Haight \& R.T. VanArdsel, eds., George Eliot: A Centenary Tribute (London: MacMillan Press, 1982) at 64-79. See also E. Jay, The Religion of the Heart: Anglican Evangelicalism and the Nineteenth-Century Novel (Oxford: Oxford University Press, 1979) at 54-64, 207-43.

Eliot, ibid. at 101.

lbid.

Ibid. 
practice and precedent. It is a jurisprudence which is rooted in an appreciation of humanity, and of humanitas, of charity and sympathy and the "nameless, unremembered, acts/ Of kindness and of love" with which Wordsworth hoped to overcome positive political ideologies. It is a jurisprudence that listens to the "still, sad music of humanity," one which is excited by the political imagination, and pained by it too. It is a jurisprudence which understands Wordsworth's disgust upon encountering a gibbet on Salisbury Plain, and which also appreciates that a world in which millions of "hungerbitten" children continue to die for want of food is one in which the humanity of all is degraded.

It is nice to think that it could be the jurisprudence of an age to come. For at the "end" of the critique of modernity, when the particular jurisprudences have been "questioned" and their conceptions of "rights" have been banished, when the archane debates between natural lawyers and positivists, moderns and post-moderns have run their weary course, there is still humanity and its craving for justice, for charity and for sympathy. The time has come for legal theory to listen to this craving, and to answer it. 